\title{
The Association Between a Large Molecular Mass Plasmid and Virulence in a Strain of Salmonella pullorum
}

\author{
By P. A. BARROW* AND M. A. LOVELL \\ AFRC Institute for Animal Health, Houghton Laboratory, Houghton, Huntingdon, \\ Cambridgeshire PE17 2DA, UK
}

(Received 21 March 1988; revised 2 May 1988)

\begin{abstract}
Eight strains of Salmonella pullorum isolated from epidemiologically independent cases of pullorum disease (bacillary white diarrhoea) in young chickens possessed at least one large molecular mass plasmid in addition to smaller molecular mass plasmids. The $85 \mathrm{~kb}$ large plasmid, designated pBL001, of one of these strains was 'tagged' with an ampicillin resistance marker by the insertion of transposon $\mathrm{Tn} 3$. The plasmid was eliminated by passage in nutrient broth containing acridine orange. It was reintroduced into the strain from which it had been eliminated by mobilization using the $\mathrm{F}$ plasmid. Following oral inoculation of newly hatched Rhode Island Red chickens, the parent strain produced a high level of mortality $(71 \%)$ with characteristic signs of pullorum disease. Following intramuscular inoculation of chickens of the same age, the bacterial $L_{50}$ was $\left(\log _{10}\right.$ c.f.u.) $3.38 \pm 0.43$ (mean \pm SEM). The derivative lacking pBL001 produced no mortality or morbidity when inoculated orally and the bacterial $L_{50}$ value increased to $\left(\log _{10}\right.$ c.f.u.) $5 \cdot 54 \pm 0 \cdot 28$. This increase was statistically significant $\left(\chi^{2}=13.6\right.$, $P<0.01)$. Reintroduction of pBL001 restored virulence as gauged by oral inoculation of chickens $\left(62 \%\right.$ mortality) and by the intramuscular bacterial $L_{50}$ value $\left(\log _{10}\right.$ c.f.u. $=3.78 \pm 0 \cdot 25)$. These values were not significantly different to those produced by the parent strain $\left(\chi^{2}=0.59, P=0.4\right.$ and $\chi^{2}=0.66, P=0.5$, respectively). Following oral inoculation, the pBL001-cured derivative was less invasive than the parent strain and following intramuscular inoculation it persisted for a shorter period than the parent strain in the liver, spleen and the leg muscle into which it had been inoculated. In addition, the parent strain, but not the pBL001-cured derivative, localized in large numbers in the myocardium where it produced lesions typical of pullorum disease. Both the parent strain and the pBL001-cured derivative were serum resistant in the presence of rabbit serum and grew equally well in chick serum and broth.
\end{abstract}

\section{INTRODUCTION}

Recent studies have indicated that large molecular mass plasmids are required for the virulence of several serotypes of Salmonella which are capable of producing systemic disease in animals and man. These include Salmonella typhimurium, S. dublin, S. enteritidis, S. cholerae-suis, S. paratyphi C and S. abortus-ovis (Jones et al., 1982; Terakado et al., 1983; Popoff et al., 1984; Baird et al., 1985; Helmuth et al., 1985; Nakamura et al., 1985). The importance of an $85 \mathrm{~kb}$ plasmid in the virulence of $S$. typhimurium was demonstrated by Jones et al. (1982), who showed that curing the plasmid produced strains which were less virulent for mice; reintroduction of the plasmid restored virulence. A similar relationship between virulence for the mouse and possession of an $80 \mathrm{~kb}$ plasmid by $S$. dublin was demonstrated by Chikami et al. (1985) by curing and reintroduction of the plasmid. Studies with $S$. enteritidis relied only on the elimination of the large plasmid to demonstrate an association with virulence (Nakamura et al., 1985).

Abbreviation: RIR, Rhode Island Red. 
A recent study (Barrow et al., 1987 b) showed that an $85 \mathrm{~kb}$ plasmid present in $S$. gallinarum was responsible for the ability of this strain to produce fowl typhoid, an economically important disease of poultry. This work indicated that the plasmid was responsible for the ability of this serotype to invade via the alimentary tract and also to survive and grow in the cells of the reticuloendothelial system. In contrast, the invasiveness of $S$. dublin (Manning et al., 1986) and of S. typhimurium (Hackett et al., 1986; Pardon et al., 1986; Gulig \& Curtiss, 1987) is thought to be chromosomally mediated.

Salmonella pullorum and $S$. gallinarum are generally regarded as biotypes of the same serotype. $S$. pullorum produces 'pullorum disease', otherwise known as bacillary white diarrhoea, in young and, to a lesser extent, adult chickens, with considerable mortality and reduced egg production (Gordon \& Jordan, 1982). Barrow et al. (1987b) found that one strain of $S$. pullorum had a large molecular mass plasmid which showed considerable homology with the $85 \mathrm{~kb}$ plasmid of $S$. gallinarum. The present study investigated an association between this plasmid and the ability of the $S$. pullorum strain to produce bacillary white diarrhoea in chickens. The role of the plasmid in the pathogenesis of the disease is also reported.

\section{METHODS}

Bacterial strains. Eight strains of $S$. pullorum were isolated from epidemiologically separate cases of bacillary white diarrhoea in chickens. They were maintained on Dorset egg slopes at $4{ }^{\circ} \mathrm{C}$. One of them, S. pullorum strain 3 , was virulent for chickens when inoculated by the oral route (Smith \& Tucker, 1980). In experiments in which $S$. pullorum organisms were inoculated orally, spontaneous chromosomal mutants resistant to nalidixic acid (Nalr), produced by the method of Smith \& Tucker (1980), were used. These authors showed that Nal ${ }^{\mathrm{r}}$ mutants of Salmonella strains were no less virulent for chickens than were the parent strains. The designation of $S$. pullorum strain 3 and its derivatives produced by procedures described below are shown in Table 1 . Broth cultures were grown in $10 \mathrm{ml}$ nutrient broth (Oxoid CM1) in a shaking water bath $\left(100\right.$ strokes $\left.\min ^{-1}\right)$ at $37^{\circ} \mathrm{C}$ for $24 \mathrm{~h}$. These usually contained between $5 \times 10^{8}$ and $1 \times 10^{9}$ c.f.u. $\mathrm{ml}^{-1}$.

Chickens. These were from a specified-pathogen-free Rhode Island Red (RIR) flock. Their sex was not determined. Their rearing conditions and diet were described by Smith \& Tucker (1975).

Plasmid isolation. DNA was visualized by the method of Hansen \& Olsen (1978). Electrophoresis of plasmid DNA was done using $0.7 \%$ agarose gels.

The size of the large plasmid was estimated by direct comparison with the $85 \mathrm{~kb}$ plasmid of $S$. typhimurium, the $70 \mathrm{~kb}$ plasmid of $S$. dublin and the $85 \mathrm{~kb}$ plasmid of $S$. gallinarum (Barrow et al., 1987b). The size of small plasmids was estimated by comparison with the $2.5 \mathrm{~kb}$ plasmid in $S$. gallinarum 9 (Barrow et al., $1987 \mathrm{~b}$ ).

Transposon mutagenesis and plasmid curing. To assist in curing, the large plasmid in strain 3 (designated pBL001) was 'tagged' with transposon Tn3, coding for ampicillin resistance. A temperature-sensitive tetracycline resistance (Tetr) plasmid containing Tn3 (pMB501; Binns et al., 1985) was introduced into $S$. pullorum strain 3 by transformation (Kushner, 1978). After incubation at a restrictive temperature $\left(42^{\circ} \mathrm{C}\right)$ the insertion of the transposon into the large plasmid was verified by the ampicillin resistance $\left(A m p^{r}\right)$ and tetracycline sensitivity

Table 1. S. pullorum strain 3 and its derivatives

$\begin{gathered}\text { Designation } \\ \text { of strain }\end{gathered}$
3
$3 \mathrm{Nal}^{\mathrm{r}}$
$3(\mathrm{Tn} 3)$
$3(\mathrm{Tn} 3) \mathrm{Spc}^{\mathrm{r}}$
$3\left(\mathrm{pBL} 001^{-}\right)$
$3\left(\mathrm{pBL} 001^{-}\right) \mathrm{Nal}^{\mathrm{r}}$
$3(\mathrm{Tn} 3) \mathrm{Nal}^{\mathrm{r}}$

Properties/derivation

Parental field strain (Smith \& Tucker, 1980). Amps $\mathrm{Nal}^{\mathrm{s}}$

A Nalr mutant of strain 3 used in experiment shown in Table 3

Strain 3 with pBL001 tagged by Tn3. Amp ${ }^{r} \mathrm{Nal}^{\text {s }}$

A spontaneous chromosomal $\mathrm{Spc}^{r}$ mutant of strain $3(\operatorname{Tn} 3)$. $\mathrm{Amp}^{\mathrm{r}} \mathrm{Nal}^{\mathrm{s}}$

Strain 3(Tn3) from which pBLO01 had been cured by acridine orange. Ampr $\mathrm{Nal}^{\mathrm{s}}$

A Nalr mutant of strain 3(pBL001-)

Strain 3(pBL001-) Nalr into which pBL001::Tn3 had been introduced from strain $3(\operatorname{Tn} 3) \mathrm{Spc}^{r}$ by mobilization with the $\mathrm{F}$ plasmid. Amp ${ }^{\mathrm{r}} \mathrm{Nal}^{\mathrm{r}}$

\section{Possession of large molecular mass plasmid}

pBL001

$\mathrm{pBL001}$

pBL001:: Tn3

pBL001 : : Tn3

Not present (pBL001-)

Not present (pBL001-)

pBL001 : :Tn3 
$\left(\mathrm{Tet}^{\mathrm{s}}\right)$ of the host, coupled with no apparent increase in the molecular mass of the small plasmid. The strain thus produced was designated $3(\operatorname{Tn} 3)$.

The Tn3-labelled plasmid (pBL001::Tn3) in this strain was cured by overnight growth in nutrient broth containing $600 \mu \mathrm{g}$ acridine orange $\mathrm{ml}^{-1}$. Plasmid loss was verified by sensitivity to ampicillin and by electrophoresis. This strain was designated 3(pBL001-).

Bacterial mating procedures. To reintroduce $\mathrm{pBL} 001$ into strain $3\left(\mathrm{pBL} 001^{-}\right)$, a three-factor mating was used. The F plasmid present in a prototrophic E. coli K12 strain (proto) (Smith, 1978) was used to mobilize pBL001:: Tn3 from strain $3(\operatorname{Tn} 3) \mathrm{Spc}^{\mathrm{r}}$ (spectinomycin resistant) into a $\mathrm{Nal}^{\mathrm{r}}$ (nalidixic acid resistant) mutant of $S$. pullorum strain $3\left(\mathrm{pBL} 001^{-}\right)$. Mating was done by incubation at $37^{\circ} \mathrm{C}$ for $18 \mathrm{~h}$ followed by a further $8 \mathrm{~h}$ at $20^{\circ} \mathrm{C}$; the mating mixture was then plated on $\mathrm{L}$ agar (Lennox, 1955) containing ampicillin $\left(100 \mu \mathrm{g} \mathrm{ml}^{-1}\right)$ and sodium nalidixate $\left(20 \mu \mathrm{g} \mathrm{ml}^{-1}\right)$. Colonies were checked for spectinomycin sensitivity to ensure that they were not spontaneous $\mathrm{Nal}^{\mathrm{r}}$ mutants of the intermediate donor. They were also tested for their sensitivity to the F-specific bacteriophage MS2 (Davis et al., 1961) and for agglutination by acriflavine (Smith, 1965b) and O-specific antisera (BurroughsWellcome, UK).

Virulence and pathogenicity studies. Newly hatched RIR chickens (less than $24 \mathrm{~h}$ old) were used for oral and intramuscular virulence assessments. Oral inoculation of undiluted broth cultures and intramuscular inoculation of decimal dilutions of broth cultures were done as described previously (Barrow et al., 1987 b). The numbers of deaths over a four week period were recorded and the percentage mortality and $\mathrm{LD}_{50}$ were calculated. The $\mathrm{LD}_{50}$ values were calculated using the MLP statistical package (Rothamsted Experimental Station, Harpenden, UK), which follows conventional methods of probit analysis (Finney, 1964). Oral LD $_{50}$ values were not calculated since the alimentary flora of the newly-hatched chicken is simple (Smith, 1965a), allowing small numbers of microorganisms to multiply extensively, thus making an $\mathbf{L D}_{50}$ value meaningless.

To study the course of infection following oral inoculation, the strains $3 \mathrm{Nal}^{\mathrm{r}}$ and $3(\mathrm{pBL001}-) \mathrm{Nal}^{r}\left(10^{8} \mathrm{c.f}\right.$.u. in $0.1 \mathrm{ml}$ ) were inoculated orally into two groups of 40 newly hatched chickens. At intervals thereafter three chickens from each group were killed. Visceral organs were sampled and bacteriological analysis was done using the method of Barrow et al. (1987a).

Strains 3 and $3\left(\mathrm{pBLO01}^{-}\right)$were tested for their ability to survive and grow in the internal organs of the young chicken. Groups of 24 2-d-old chickens were inoculated with $10^{5}$ c.f.u. in $0.05 \mathrm{ml}$ into one of the gastrocnemius muscles. At $3 \mathrm{~d}$ intervals post-inoculation three chickens from each group were killed. Viable counts of the inoculated organisms in the liver, spleen, heart blood, heart muscle and both the inoculated and the corresponding uninoculated gastrocnemius muscle were made using MacConkey agar (Miles \& Misra, 1938).

Growth of bacteria in the yolk sac. The method has been described previously (Barrow et al., 1987a). Briefly, newly hatched chickens were inoculated directly into the yolk sac, through the body wall, with approximately $10^{3}$ organisms in $0.1 \mathrm{ml}$ Dulbecco's phosphate buffered saline (PBS, Oxoid BR14a). The chickens were killed $24 \mathrm{~h}$ later. The yolk sacs were removed and viable counts were made on their contents (Miles \& Misra, 1938).

Growth of bacteria in serum and broth. Overnight broth cultures were diluted 1 in 100 in nutrient broth and further incubated with shaking at $37^{\circ} \mathrm{C}$ for $2 \mathrm{~h}$. The cultures were centrifuged at $1500 \mathrm{~g}$ for $30 \mathrm{~min}$ and the cells resuspended in an equal volume of PBS. The suspension was diluted 20-fold with PBS and $0.03 \mathrm{ml}$ of this suspension was mixed with $1.5 \mathrm{ml}$ of nutrient broth, of normal rabbit serum or of pooled serum obtained from healthy 4-d-old chickens. In both cases the serum was prepared by allowing fresh aseptically drawn blood to clot for $2 \mathrm{~h}$ at $37^{\circ} \mathrm{C}$ followed by further incubation at $4{ }^{\circ} \mathrm{C}$ for $1 \mathrm{~h}$ before the serum was pipetted off and used immediately. The mixtures of bacteria and serum or broth were incubated statically at $37^{\circ} \mathrm{C}$. Viable counts were done on MacConkey agar at intervals thereafter (Miles \& Misra, 1938).

\section{RESULTS}

\section{Plasmid content of $S$. pullorum}

The plasmid profiles of eight epidemiologically separate strains of $S$. pullorum are shown in Fig. 1 (lanes 1-8). Seven of these strains contained one large plasmid, in four cases the plasmids were approximately $85 \mathrm{~kb}$ in size (lanes 1-4) and in three, slightly larger (lanes 5-7). One strain possessed two large plasmids (lane 8 ). In addition, each of the eight strains possessed at least one smaller plasmid of between 2.5 and $4 \mathrm{~kb}$.

One of the strains, $S$. pullorum strain 3 , was chosen for further study because it possessed one large plasmid only, of $85 \mathrm{~kb}$, designated pBL001 (Fig. 1, lane 1), and because some of the virulence characteristics of this strain had already been described (Smith \& Tucker, 1980). Transposon Tn3, which confers ampicillin resistance, was used to 'tag' pBL001, which was then cured by passage of strain $3(\operatorname{Tn} 3)$ in broth containing acridine orange. The plasmid was cured at a frequency of approximately $10^{-4}$. The pBL001-cured derivative, designated 3(pBL001-), was 


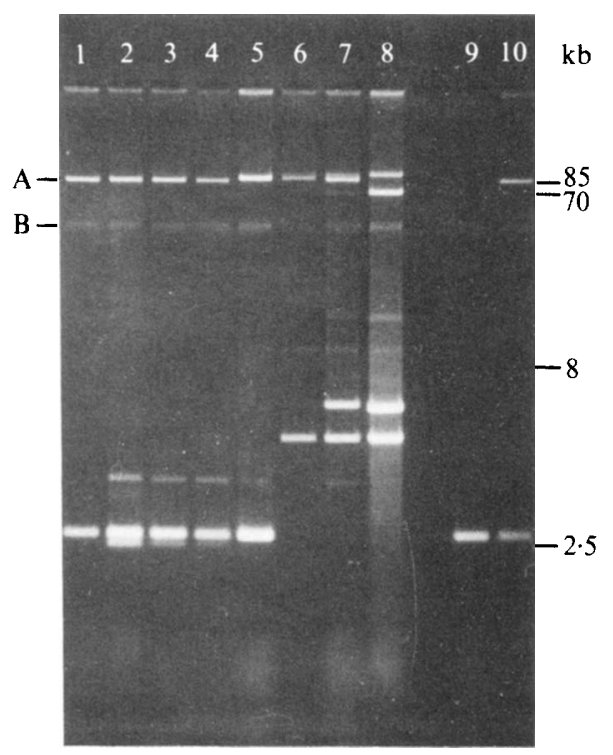

Fig. 1. Electrophoresis of $S$. pullorum plasmid DNA. Lane 1, $S$. pullorum strain 3; lanes 2-8, recently isolated field strains of $S$. pullorum; lane 9 , strain $3\left(\mathrm{pBLO01}^{-}\right)$; lane 10 , strain $3(\mathrm{Tn} 3) \mathrm{Nal}^{\mathrm{r}}$. A shows the position of the large plasmids and $B$ shows the position of chromosomal DNA. Additional smaller plasmids are also visible. Other faint bands in tracks represent multimeric forms of plasmids or plasmids with single strand 'nicks'. The positions of size markers are indicated on the right.

identified by its sensitivity to ampicillin and the absence of pBL001, confirmed by plasmid content analysis (Fig. 1, lane 9).

Plasmid pBL001 was reintroduced into a $\mathrm{Nal}^{\mathrm{r}}$ mutant of the pBL001-cured derivative, designated $3\left(\mathrm{pBLO01}^{-}\right) \mathrm{Nal}^{\mathrm{r}}$, by a three-factor mating using the $\mathrm{F}$ plasmid for mobilization (Fig. 1, lane 10). The absence of the $F$ plasmid from the final recipient, strain $3(\operatorname{Tn} 3) \mathrm{Nal}^{\mathrm{r}}$, was demonstrated by its resistance to the F-specific bacteriophage MS2. Both strains 3 and $3\left(\mathrm{pBLO01}^{-}\right)$were found to possess smooth lipopolysaccharide by absence of agglutination with acriflavine and both reacted with $\mathrm{O}$-specific antisera. No association was observed between the possession of $\mathrm{pBL} 001$ and either carbohydrate fermentation or standard biochemical tests used for the identification of the Enterobacteriaceae as determined by the API $20 \mathrm{E}$ and $50 \mathrm{CH}$ systems (API). Strains 3 and $3\left(\mathrm{pBLO01}^{-}\right)$were both serum resistant in normal rabbit serum. The growth rates of the two strains in serum obtained from healthy 4-d-old chickens and in nutrient broth were similar to each other.

We were unable to 'tag' the smaller molecular mass plasmid in strain 3 despite having examined $45 \mathrm{Amp}^{\mathrm{r}} \mathrm{Tet}^{\mathrm{s}}$ cultures for an increase in molecular mass of this plasmid, which would have been detectable after $\mathrm{Tn} 3$ insertion.

\section{Association of pBLO01 with virulence}

The virulence of $S$. pullorum strain 3 and its derivatives was assessed by oral and intramuscular inoculation of newly hatched RIR chickens (Table 2). By oral inoculation, strains 3 and $3(\operatorname{Tn} 3)$ produced mortality figures that were not significantly different from each other. Mortality commenced 11 and $10 \mathrm{~d}$, respectively, post-inoculation. In both cases the inoculated organisms were regularly re-isolated from the livers of chickens which had died. The clinical signs of the disease produced by both strains were similar. These included lethargy, anorexia, caked vents and the presence of yellow urates in the droppings. Yellowish spot-like areas of necrosis, 1-2 mm in diameter, were seen in the liver, heart and spleen of the dead chickens. By contrast, strain $3\left(\mathrm{pBLO01}^{-}\right)$killed none of the 51 chickens inoculated orally. This was significantly different $(P<0.01)$ from the mortality rate produced by strain 3 . There were no 
Table 2. Percentage mortality and $L D_{50}$ values of $S$. pullorum strain 3 and its derivatives in newly-hatched chickens

\begin{tabular}{|c|c|c|c|c|c|c|c|}
\hline \multirow[b]{3}{*}{ Strain } & \multicolumn{4}{|c|}{ Mortality } & \multicolumn{3}{|c|}{$\mathrm{LD}_{50}$} \\
\hline & \multirow{2}{*}{$\begin{array}{l}\text { No of chickens } \\
\text { inoculated } \\
\text { orally* }\end{array}$} & \multirow[b]{2}{*}{ No. dead $\dagger$} & \multicolumn{2}{|c|}{ Significance $\ddagger$} & \multirow[b]{2}{*}{$\log _{10}$ C.f.u. $\S$} & \multicolumn{2}{|c|}{ Significancet } \\
\hline & & & $\chi^{2}$ & $P$ & & $\chi^{2}$ & $P$ \\
\hline 3 & 34 & $24(71)$ & - & - & $\begin{array}{l}3.38 \pm 0.43 \\
4.62 \pm 0.33\end{array}$ & - & - \\
\hline $3(\operatorname{Tn} 3)$ & 26 & $23(88)$ & $2 \cdot 76$ & $0 \cdot 1$ & $\begin{array}{c}3 \cdot 50 \pm 0.31 \\
\text { ND }\end{array}$ & $\begin{array}{l}0.46 \\
-\end{array}$ & $\underline{0.50}$ \\
\hline $3\left(\mathrm{pBL} 001^{-}\right)$ & 51 & $0(0)$ & $13 \cdot 6$ & $<0.01$ & $\begin{array}{l}5.54 \pm 0.28 \\
5.94 \pm 0.27\end{array}$ & $\begin{array}{l}13 \cdot 6 \\
16 \cdot 27\end{array}$ & $\begin{array}{l}<0.01 \\
<0.01\end{array}$ \\
\hline $3(\operatorname{Tn} 3) \mathrm{Nal}^{\mathrm{r}}$ & 34 & $21(62) \|$ & 0.59 & 0.4 & $\begin{array}{l}3.78 \pm 0.25 \\
4.38 \pm 0.29\end{array}$ & $\begin{array}{l}0.66 \\
0.04\end{array}$ & $\begin{array}{l}0.50 \\
0.85\end{array}$ \\
\hline $\begin{array}{l}\text { ND, Not d } \\
\text { * All inoct } \\
\dagger \text { The pero } \\
\ddagger \text { Results } \\
\text { § Chicken } \\
\text { hickens per }\end{array}$ & $\begin{array}{l}\text { ns contained } 10 \\
\text { are of the total n } \\
\text { ared ftatistic } \\
\text { culated intramu } \\
\text { ion. Values are }\end{array}$ & $\begin{array}{l}\text { in } 0.1 \mathrm{~m} \\
\mathrm{r} \text { of chicke } \\
\text { nificance } \\
\text { ly (gastroc } \\
\text { for two re }\end{array}$ & $\begin{array}{l}\text { give } \\
\text { alue } \\
\text { us } n\end{array}$ & $\begin{array}{l}\text { arent } \\
\text { train } \\
\text { with }\end{array}$ & . & & es, 5 \\
\hline
\end{tabular}

signs of ill health and strain $3\left(\mathrm{pBL} 001^{-}\right)$was not re-isolated from the liver when the chickens were killed four weeks later. Plasmid pBL001 was reintroduced into a single clone of strain $3\left(\mathrm{pBLO01}^{-}\right) \mathrm{Nal}^{\mathrm{r}}$ in five separate mating experiments. In each case the virulence of the final recipient, strain $3(\operatorname{Tn} 3) \mathrm{Nal}^{\mathrm{r}}$, was tested by oral inoculation of groups of 34 chickens. The percentage mortalities produced by these five independently derived transconjugants with the significance in parentheses of the difference between the mortality value and that produced by strain 3, were $62(P=0.4), 62(P=0.4), 56(P=0.2), 50(P=0.07)$ and $35(P<0.01)$ respectively. Thus, three of the five transconjugants with pBL001 were clearly as virulent as the parent strain. In chickens which became ill and died, clinical signs were similar to those in chickens inoculated with strain 3 . Chickens began to die $9 \mathrm{~d}$ post-inoculation.

The $\mathrm{LD}_{50}$ values following intramuscular inoculation of strains $3(\operatorname{Tn} 3)$ and $3(\operatorname{Tn} 3) \mathrm{Nal}^{\mathrm{r}}$ were not significantly different from those of strain 3 . This was also the case when strains 3 and $3(\operatorname{Tn} 3) \mathrm{Nal}^{\mathrm{r}}$ were re-tested on another occasion. The $\mathrm{LD}_{50}$ values of strain $3\left(\mathrm{pBLO01}^{-}\right)$were significantly different $(P<0 \cdot 01)$ from those of strain 3 . On one occasion the $\mathrm{LD}_{50}$ was increased by a factor of 150 and on another, by a factor of 12 .

Strain 3 and $3\left(\mathrm{pBLO01}^{-}\right)$were tested for intramuscular virulence in newly hatched chickens and in 2- and 4-d-old chickens. By intramuscular inoculation the $\mathrm{LD}_{50}$ values of strain 3 at these ages were $\left(\log _{10}\right.$ c.f.u., mean \pm SEM) $4 \cdot 03 \pm 0 \cdot 38,6 \cdot 10 \pm 0 \cdot 25$ and $7 \cdot 37 \pm 0 \cdot 23$, respectively. The corresponding values for strain $3\left(\mathrm{pBL} 001^{-}\right)$were $5.55 \pm 0.31,7.63 \pm 0.27$ and $8.25 \pm 0.21$, respectively. At each age of inoculation the $L_{50}$ value of strain 3 was significantly different from that of strain $3\left(\mathrm{pBL}_{001^{-}}{ }^{-}\right.$). The significance values were $P<0.01$ at 0 and $2 \mathrm{~d}$ and $P=0.03$ at $4 \mathrm{~d}$ of age.

The course of the infection produced by strains $3 \mathrm{Nal}^{\mathrm{r}}$ and $3\left(\mathrm{pBLOO1^{- }}\right) \mathrm{Nal}^{\mathrm{r}}$

The course of infection was followed after oral inoculation of newly hatched chickens with strains $3 \mathrm{Nal}^{\mathrm{r}}$ and $3\left(\mathrm{pBLO01}^{-}\right) \mathrm{Nal}^{r}$. The results are summarized in Table 3. Soon after inoculation strain $3 \mathrm{Nal}^{\mathrm{r}}$ was isolated from the three sections of the alimentary tract and in high numbers from the contents of the caecum. By $2 \mathrm{~d}$ post-inoculation this strain was present in the liver and spleen and by $4 \mathrm{~d}$ these organisms were also present in the kidney, heart muscle and yolk sac. After $6 \mathrm{~d}$ the strain was isolated only intermittently from the alimentary tract, but was still present in the other tissues with the exception of blood and breast muscle. The strain persisted in the liver, spleen and heart throughout the experiment. Isolations were made from 
Table 3. Isolation of mutants of S. pullorum strains $3 \mathrm{Nal}^{\mathrm{r}}$ and $3\left(\mathrm{pBLOOI^{- } )} \mathrm{Nal}^{\mathrm{r}}\right.$ from the viscera of newly hatched chickens at intervals after oral inoculation

All chickens were inoculated orally with $10^{8}$ c.f.u. in $0.1 \mathrm{ml}$. Viable counts are expressed as median values from three chickens. Deaths occurred from $10 \mathrm{~d}$ post-inoculation with $S$. pullorum $3 \mathrm{Nal}^{\mathrm{r}}$.

\begin{tabular}{|c|c|c|c|c|c|c|c|c|c|c|c|}
\hline & & & & & $\log _{1}$ & C.f.u & $\mathrm{g}$ tis & )$\left.^{-1}\right]$ & & & \\
\hline & & & & & $\mathrm{Da}$ & post & ocul & on: & & & \\
\hline Strain & Organ/tissue & $\frac{1}{4}$ & $\frac{1}{2}$ & 1 & 2 & 4 & 6 & 8 & 10 & 17 & 24 \\
\hline $3 \mathrm{Nal}^{\mathrm{r} *}$ & Blood & $\mathrm{N}$ & $\mathbf{N}$ & $\mathbf{N}$ & $\mathbf{N}$ & $\mathbf{N}$ & $\mathbf{N}$ & $\mathbf{N}$ & $2 \cdot 0$ & $\mathbf{N}$ & $\mathrm{N}$ \\
\hline & Kidney & $\mathbf{N}$ & $\mathbf{N}$ & $\mathbf{N}$ & $\mathrm{N}$ & $2 \cdot 9$ & $2 \cdot 5$ & $4 \cdot 4$ & $3 \cdot 5$ & $\mathbf{N}$ & $\mathrm{N}$ \\
\hline & Heart muscle & $\mathbf{N}$ & $\mathbf{N}$ & $\mathbf{N}$ & $\mathbf{N}$ & $3 \cdot 5$ & $4 \cdot 6$ & $5 \cdot 0$ & $5 \cdot 0$ & $5 \cdot 2$ & $5 \cdot 4$ \\
\hline & Liver & $\mathbf{N}$ & $\mathbf{N}$ & $\mathbf{N}$ & $3 \cdot 0$ & $4 \cdot 5$ & $3 \cdot 7$ & $4 \cdot 7$ & 3.5 & $2 \cdot 0$ & $2 \cdot 0$ \\
\hline & Spleen & $\mathrm{N}$ & $\mathrm{N}$ & $\mathrm{N}$ & $2 \cdot 0$ & $4 \cdot 8$ & $3 \cdot 3$ & $5 \cdot 0$ & $3 \cdot 6$ & $2 \cdot 8$ & $4 \cdot 0$ \\
\hline & Yolk sac & $\mathbf{N}$ & $\mathbf{N}$ & $\mathbf{N}$ & $\mathrm{N}$ & $2 \cdot 0$ & $6 \cdot 5$ & 6.7 & $8 \cdot 4$ & $6 \cdot 4$ & $6 \cdot 5$ \\
\hline & Crop contents & $5 \cdot 0$ & $5 \cdot 2$ & $4 \cdot 7$ & $3 \cdot 3$ & $3 \cdot 7$ & $\mathrm{~N}$ & $3 \cdot 3$ & $\mathbf{N}$ & $\mathbf{N}$ & $2 \cdot 7$ \\
\hline & Jejunum contents & $4 \cdot 3$ & $3 \cdot 3$ & $\mathbf{N}$ & $\mathbf{N}$ & $\mathbf{N}$ & $\mathbf{N}$ & $\mathbf{N}$ & $\mathbf{N}$ & $\mathbf{N}$ & $\mathrm{N}$ \\
\hline & Caecal contents & 7.9 & $9 \cdot 5$ & $9 \cdot 0$ & $8 \cdot 6$ & 4.9 & $\mathbf{N}$ & $3 \cdot 7$ & $\mathbf{N}$ & $6 \cdot 8$ & $5 \cdot 3$ \\
\hline $3\left(\mathrm{pBL} 001^{-}\right) \mathrm{NaI}^{\mathrm{r} \dagger}$ & Liver & $\mathbf{N}$ & $\mathbf{N}$ & $\mathrm{N}$ & $\mathbf{N}$ & $\mathbf{N}$ & $\mathbf{N}$ & $\mathbf{N}$ & $\mathbf{N}$ & $\mathbf{N}$ & $\mathbf{N}$ \\
\hline & Spleen & $\mathbf{N}$ & $\mathbf{N}$ & $\mathbf{N}$ & $\mathbf{N}$ & $\mathbf{N}$ & $\mathbf{N}$ & $2 \cdot 6$ & $\mathbf{N}$ & $\mathbf{N}$ & $\mathbf{N}$ \\
\hline & Crop contents & $5 \cdot 2$ & $5 \cdot 3$ & 3.6 & $2 \cdot 6$ & $\mathbf{N}$ & $\mathbf{N}$ & $\mathbf{N}$ & $\mathbf{N}$ & $\mathbf{N}$ & $\mathbf{N}$ \\
\hline & Jejunum contents & $4 \cdot 2$ & $2 \cdot 5$ & $\mathbf{N}$ & $\mathbf{N}$ & $\mathbf{N}$ & $\mathbf{N}$ & $\mathbf{N}$ & $\mathbf{N}$ & $\mathrm{N}$ & $\mathbf{N}$ \\
\hline & Caecal contents & $8 \cdot 2$ & $9 \cdot 5$ & $9 \cdot 6$ & 8.9 & $2 \cdot 5$ & $\mathbf{N}$ & $\mathbf{N}$ & $\mathbf{N}$ & $\mathbf{N}$ & $\mathbf{N}$ \\
\hline
\end{tabular}

* Counts for breast muscle were zero at all times.

+ Counts for blood, breast muscle, kidney, heart muscle, yolk sac and jejunal contents were zero at all times. $\mathrm{N}$, Median count $\left(\log _{10}\right)<2 \cdot 0$.

the blood at $10 \mathrm{~d}$, by which time chickens usually started to die. At this time, whitish spot-like areas of necrosis were also noticed in the heart. The numbers of organisms in the yolk sac increased to a maximum at $10 \mathrm{~d}$ and then remained at slightly lower levels thereafter. By contrast, strain $3\left(\mathrm{pBLO01}^{-}\right) \mathrm{Nal}^{\mathrm{r}}$ was isolated infrequently from the spleen and was not isolated from the liver, heart or other organs. Although, as with strain $3 \mathrm{Nal}^{\mathrm{r}}$, strain $3\left(\mathrm{pBL001}{ }^{-}\right) \mathrm{Nal}^{\mathrm{r}}$ was found in high numbers in the alimentary tract soon after inoculation when the indigenous gut flora is very rudimentary, it subsequently disappeared from the gut and was not re-isolated.

Survival of strains 3 and $3\left(\mathrm{pBLO01} 1^{-}\right)$in the tissues following intramuscular inoculation

The recovery of strains 3 and $3\left(\mathrm{pBLO01}^{-}\right.$) from various tissues after inoculation into one of the gastrocnemius muscles of 2-d-old chickens is shown in Table 4 . At $2 \mathrm{~h}$ post-inoculation the highest numbers of organisms of both strains were found in the inoculated muscle and the spleen. At this time, strain $3\left(\mathrm{pBLO01}^{-}\right)$but not strain 3 was also isolated from the liver and heart blood in lower numbers.

The chickens inoculated with strain 3 increasingly showed signs of disease, with deaths occurring from $18 \mathrm{~d}$ post-inoculation. The strain was isolated from the liver and in increasing numbers from the spleen of these chickens and white areas of necrosis appeared on the surface of both organs. Liver lesions were small and localized, while spleen lesions were generally larger and more diffuse. Bacteria persisted in the inoculated gastrocnemius muscle throughout the experiment and localized abscesses were observed in the muscle. These had disappeared by $18 \mathrm{~d}$. Organisms were isolated in increasing numbers from the heart muscle, but were not isolated either from cardiac blood or from the uninoculated gastrocnemius muscle. By day nine small lesions were visible in the heart muscle. Later in the experiment the lesions had enlarged until two or three lesions accounted for $20-60 \%$ of the surface of the heart. The pericardium did not appear to be affected although pericardial fluid was not cultured.

Strain $3\left(\mathrm{pBLOO1}^{-}\right)$was only isolated from the spleen and inoculated muscle and in decreasing numbers until it disappeared from these tissues by $24 \mathrm{~d}$ and $15 \mathrm{~d}$ respectively. The chickens in this group remained healthy throughout and the organs appeared macroscopically normal. 
Table 4. Isolation of $S$. pullorum strains 3 and $3\left(p^{2} L_{001}\right)$ from the viscera of 2-d-old chickens after intramuscular inoculation

\begin{tabular}{|c|c|c|c|c|c|c|c|c|c|c|}
\hline & & & & & $\log _{10}$ & f.u. & tissue) & & & \\
\hline & & & & & Days & ost-in & ulatior & & & \\
\hline Strain & Organ/tissue & $\frac{1}{12}$ & 3 & 6 & 9 & 12 & 15 & 18 & 24 & 30 \\
\hline 3 & Liver & $\mathbf{N}$ & $4 \cdot 2$ & $3 \cdot 8$ & $3 \cdot 3^{*}$ & $3 \cdot 3^{*}$ & $4 \cdot 2^{*}$ & $\mathrm{~N}^{*}$ & $2 \cdot 0^{*}$ & $\mathbf{N}$ \\
\hline & Spleen & $4 \cdot 1$ & $4 \cdot 5$ & $4 \cdot 7^{*}$ & $3 \cdot 6$ & $4 \cdot 4^{*}$ & $4 \cdot 8^{*}$ & $3 \cdot 2^{*}$ & $3 \cdot 1$ & $3 \cdot 8$ \\
\hline & Heart muscle & $\mathbf{N}$ & $2 \cdot 3$ & $3 \cdot 1$ & $3 \cdot 5^{*}$ & $4 \cdot 8^{*}$ & $3 \cdot 7^{*}$ & $4 \cdot 0^{*}$ & $\mathrm{~N}^{*}$ & $4 \cdot 5^{*}$ \\
\hline & Heart blood & $\mathbf{N}$ & $\mathbf{N}$ & $\mathbf{N}$ & $\mathbf{N}$ & $\mathbf{N}$ & $\mathbf{N}$ & $\mathbf{N}$ & $\mathbf{N}$ & $\mathbf{N}$ \\
\hline & Inoculated muscle & $5 \cdot 2$ & $5 \cdot 2$ & $5 \cdot 8$ & $5 \cdot 0$ & $4 \cdot 7$ & $6 \cdot 0$ & $4 \cdot 8$ & $2 \cdot 9$ & $2 \cdot 5$ \\
\hline & Uninoculated muscle & $\mathbf{N}$ & $\mathbf{N}$ & $\mathbf{N}$ & $\mathbf{N}$ & $\mathbf{N}$ & $\mathbf{N}$ & $\mathbf{N}$ & $\mathbf{N}$ & $\mathbf{N}$ \\
\hline $3\left(\mathrm{pBLO01}^{-}\right)$ & Liver & $2 \cdot 0$ & $\mathbf{N}$ & $\mathbf{N}$ & $\mathbf{N}$ & $\mathbf{N}$ & $\mathbf{N}$ & $\mathbf{N}$ & $\mathbf{N}$ & $\mathbf{N}$ \\
\hline & Spleen & $4 \cdot 5$ & $5 \cdot 0$ & $4 \cdot 2$ & $4 \cdot 1$ & $2 \cdot 6$ & $2 \cdot 9$ & $2 \cdot 0$ & $\mathbf{N}$ & $\mathbf{N}$ \\
\hline & Heart muscle & $\mathbf{N}$ & $\mathbf{N}$ & $\mathbf{N}$ & $\mathbf{N}$ & $\mathbf{N}$ & $\mathbf{N}$ & $\mathbf{N}$ & $\mathbf{N}$ & $\mathbf{N}$ \\
\hline & Heart blood & $2 \cdot 0$ & $\mathbf{N}$ & $\mathbf{N}$ & $\mathbf{N}$ & $\mathbf{N}$ & $\mathbf{N}$ & $\mathbf{N}$ & $\mathbf{N}$ & $\mathbf{N}$ \\
\hline & Inoculated muscle & $4 \cdot 5$ & $5 \cdot 2$ & $4 \cdot 5$ & $4 \cdot 6$ & $3 \cdot 5$ & $\mathbf{N}$ & $\mathbf{N}$ & $\mathbf{N}$ & $\mathbf{N}$ \\
\hline & Uninoculated muscle & $\mathbf{N}$ & $\mathrm{N}$ & $\mathbf{N}$ & $\mathbf{N}$ & $\mathbf{N}$ & $\mathrm{N}$ & $\mathbf{N}$ & $\mathbf{N}$ & $\mathbf{N}$ \\
\hline
\end{tabular}

$\mathrm{N}$, Median count $\left(\log _{10}\right)<2 \cdot 0$.

* Macroscopic lesions observed.

Growth of bacteria in the yolk sac

Viable counts of strains 3 and $3\left(\mathrm{pBLO01}^{-}\right)$in the yolk sacs of two groups of five newly hatched chickens were made $24 \mathrm{~h}$ post-inoculation with $10^{3}$ organisms. The median viable count of strain 3 ( $\log _{10}$ c.f.u.) with the range in parentheses was $6.4(3.2-8.4)$ and that of strain $3\left(\mathrm{pBL} 001^{-}\right)$was $6 \cdot 0(4 \cdot 6-8 \cdot 4)$.

\section{DISCUSSION}

Associations between virulence in Salmonella serotypes that routinely produce invasive systemic disease and the possession of large molecular mass plasmids have been reported by Jones et al. (1982); Terakado et al. (1983); Popoff et al. (1984); Baird et al. (1985); Helmuth et al. (1985); Nakamura et al. (1985) and Barrow et al. (1987 b). However, in order to demonstrate the association between the possession of a plasmid and a virulence characteristic it must be shown not only that curing the plasmid is associated with loss of virulence, but that virulence can be restored by reintroduction of the plasmid. This is particularly true where relatively harsh chemical methods are used for plasmid curing, methods which might conceivably affect other non-plasmid mediated functions.

In the present study elimination of the large plasmid (pBL001) of a $S$. pullorum strain was associated with complete loss of virulence when inoculated orally, the natural route of infection. By the parenteral route there was a decrease in virulence by 150 -fold on one occasion and 12 -fold on another, which is, however, a considerably smaller reduction in virulence than that seen following inoculation with $S$. gallinarum and other Salmonella serotypes. Reintroduction of pBL001 restored oral and parenteral virulence, thereby fulfilling the above criterion for a causal association. This criterion was, however, only fulfilled by testing the virulence of transconjugants [strain $3(\operatorname{Tn} 3) \mathrm{Nal}^{\mathrm{r}}$ ] which had resulted from several independent mating experiments to restore pBL001 to strain $3\left(\mathrm{pBL001}^{-}\right) \mathrm{Nal}^{\mathrm{r}}$. Some of the recipients were of significantly reduced virulence. This was possibly the result of preferential conjugation between the donor strain, $3(\mathrm{Tn} 3) \mathrm{Spc}^{r}$, and individual organisms of strain $3\left(\mathrm{pBL001}^{-}\right) \mathrm{Nal}^{\mathrm{r}}$ which were mutants of reduced virulence (Smith, 1972; Smith \& Tucker, 1979). Since at least three of the clones tested were of comparable virulence to the parental strain 3 it seemed unlikely that in these cases the acridine orange treatment used in curing had produced a significant reduction in 
virulence other than that associated with plasmid loss. At this stage, and without more detailed plasmid analysis, it is impossible to say whether the large plasmids of the other strains of $S$. pullorum examined were also involved in virulence. In addition to $85 \mathrm{~kb}$ plasmids both $S$. gallinarum (Barrow et al., 1987 b) and $S$. pullorum possess small plasmids. Whereas the $2.5 \mathrm{~kb}$ plasmid possessed by $S$. gallinarum strain 9 did not contribute to virulence, the role, if any, of that in the $S$. pullorum strain studied could not be established herein as we were unable to obtain Tn 3 insertions in the small plasmid of strain 3.

Studies on the pathogenesis of the infection produced by the strains $3 \mathrm{Nal}^{\mathrm{r}}$ and $3\left(\mathrm{pBLO01}^{-}\right) \mathrm{Nal}^{\mathrm{r}}$ revealed that $\mathrm{pBL001}$ was associated with more than one stage of the pathogenesis as was also observed with $S$. gallinarum strain 9 (Barrow et al., 1987b). Its presence was associated with invasiveness, since following oral inoculation strain $3 \mathrm{Nal}^{\mathrm{r}}$ was isolated from the liver and spleen after a shorter period of time than was strain 3(pBL001-) $\mathrm{Nal}^{\mathrm{r}}$, despite the presence of high numbers of both strains in the alimentary tract. Whether loss of pBL001 resulted in reduced invasiveness per se or in reduced translocation of organisms between the gut and the reticuloendothelial system as suggested by Gulig \& Curtiss (1987) for $S$. typhimurium is as yet unclear. Results showed that the chickens became considerably more resistant to intramuscular inoculation after a few days. Thus, slower invasion or translocation must consequently lead to a reduction in the severity of the infection. These results are in contrast to those relating to $S$. dublin (Manning et al., 1986) and $S$. typhimurium (Hackett et al., 1986; Pardon et al., 1986) in which invasion is thought to be chromosomally mediated.

Strain $3 \mathrm{Nal}^{\mathrm{r}}$, but not strain $3\left(\mathrm{pBLO01}^{-}\right) \mathrm{Nal}^{\mathrm{r}}$, was isolated in considerable numbers from the yolk sac following oral inoculation. Since strains 3 and $3\left(\mathrm{pBLO01}^{-}\right) \mathrm{Nal}^{\mathrm{r}}$ both grew well in vivo in the yolk sac following direct inoculation into this organ it is likely that the isolation of only strain $3 \mathrm{Nal}^{\mathrm{r}}$ from the yolk sac following oral inoculation can also be attributed to its greater invasiveness. Similar observations were made with strains of $S$. typhimurium of different degrees of invasiveness (Barrow et al., 1987a).

The possession of pBL001 was also associated with increased ability to grow in tissues. Despite the absence of an association between pBL001 and serum resistance, strain 3 persisted in the inoculated gastrocnemius muscle for a much longer period than did strain 3(pBL001-). The reason for the particular localization in the myocardium following intra-muscular and oral inoculation is unclear, particularly since the strain did not localize in uninoculated gastrocnemius muscle.

Salmonella in general is thought to be an intracellular pathogen (Suter \& Ramseier, 1964; Takeuchi, 1967; Takeuchi \& Sprinz, 1967; Popiel \& Turnbull, 1985). The inability to culture Salmonella from either the heart blood or uninoculated muscle tends to support this contention. Serum resistance per se is, therefore, unlikely to be of major importance as a virulence characteristic. The large plasmid of $S$. gallinarum strain 9 was not involved in serum resistance (Barrow et al., 1987b). Similarly plasmid pBL001 appeared to contribute little to this characteristic in $S$. pullorum strain 3. This agrees with some observations with $S$. typhimurium (Pardon et al., 1986; Gulig \& Curtiss, 1987), but contrasts with other findings on that serotype (Jones et al., 1982; Hackett et al., 1986; 1987; Vandenbosch et al., 1987). It is unclear at this stage whether some authors have examined strains which possessed unidentified chromosomal lesions or whether in some cases serum resistance might be involved in virulence. Even if serum resistance is not directly involved in the pathogenesis of salmonellosis it may conceivably act as a marker for some other virulence characteristic in S. typhimurium.

Barrow et al. (1987b) showed by Southern hybridization that there was considerable homology between the $85 \mathrm{~kb}$ plasmid of $S$. pullorum strain 3 and the $85 \mathrm{~kb}$ plasmid of $S$. gallinarum strain 9. Similarities between these two strains in plasmid-mediated invasiveness and ability to grow in the tissues would thus not be surprising. Further studies are now under way to define the relationship between the plasmid-mediated functions in $S$. pullorum and S. gallinarum. 


\section{REFERENCES}

Baird, G. D., Manning, E. J. \& Jones, P. W. (1985) Evidence for related virulence sequences in plasmids of Salmonella dublin and Salmonella typhimurium. Journal of General Microbiology 131, 1815-1823.

Barrow, P. A., Huggins, M. B., Lovell, M. A. \& Simpson, J. M. (1987a). Observations on the pathogenesis of experimental Salmonella typhimurium infection in chickens. Research in Veterinary Science 42, 194-199.

Barrow, P. A., Simpson, J. M., Lovell, M. A. \& BinNs, M. M. (1987b). Contribution of Salmonella gallinarum large plasmid toward virulence in fowl typhoid. Infection and Immunity 55, 388-392.

Binns, M. M., Vaughan, S. \& Timmis, K. N. (1985). Oantigens are essential virulence factors of Shigella sonnei and Shigella dysenteriae 1. Zentralblatt für Bakteriologie und Hygiene (Abteilung I, Originale B) 181, 197-205.

Chikami, G. K., Fierer, J. \& Guiney, D. G. (1985). Plasmid-mediated virulence in Salmonella dublin demonstrated by use of a Tn5-oriT construct. Infection and Immunity 50, 420-424.

Davis, J. E., Strauss, J. H. \& SinSheimer, R. L. (1961). Bacteriophage MS2: another RNA phage. Science 134, 1427.

FINNEY, D. J. (1964). Statistical Methods in Biological Assay. London: Charles Griffin.

GORDON, R. F. \& JORDAN, F. T. W. (1982). Poultry Diseases. London: Baillière-Tindall.

Gulig, P. A. \& Curtiss, R. (1987). Plasmid associated virulence of Salmonella typhimurium. Infection and Immunity 55, 2891-2901.

Hackett, J., Kotlarski, I., Mathan, V., Pranck, K. \& Rowley, D. (1986). The colonization of Peyers Patches by a strain of Salmonella typhimurium cured of the cryptic plasmid. Journal of Infectious Diseases 153, 1119-1125.

HacketT, J., Wyk, P., ReEves, P. \& Mathan, V. (1987). Mediation of serum resistance in Salmonella typhimurium by an 11 kilodalton polypeptide encoded by the cryptic plasmid. Journal of Infectious Diseases 155, 540-549.

HANSEN, J. B. \& OLSEN, R. H. (1978). Isolation of large bacterial plasmids and characterization of the P2 incompatibility group plasmids pMG1 and pMG5. Journal of Bacteriology 135, 227-238.

Helmuth, R., Stephan, R., Bunge, C., Hoog, B., SteinbeCK, A. \& Bulling, E. (1985). Epidemiology of virulence-associated plasmids and outer membrane protein patterns within seven common Salmonella serotypes. Infection and Immunity 48, 175182.

JoNeS, G. W., Rabert, D. K., SvinaRich, D. M. \& WhitfiELD, H. J. (1982). Association of adhesive, invasive and virulent phenotypes of Salmonella typhimurium with autonomous 60 -megadalton plasmids. Infection and Immunity 38, 476-486.

KUSHNER, S. R. (1978). An improved method for transformation of Escherichia coli with ColE1derived plasmids. In Genetic Engineering, pp. 17-23. Edited by H. B. Boyer \& S. Nicosia. Amsterdam: Elsevier/North Holland.

LENNOX, E. S. (1955). Transduction of linked genetic characters of the host by bacteriophage P1. Virology 1, 190-206.
Manning, E. J., Baird, G. D. \& Jones, P. W. (1986). The role of plasmid genes in the pathogenicity of Salmonella dublin. Journal of Medical Microbiology 21, 239-243.

MiLes, A. A. \& MiSRA, S. S. (1938). The estimation of the bactericidal power of blood. Journal of Hygiene 38, 732-749.

Nakamura, M., Sato, S., Ohya, T., Suzuki, S. \& IKEDA, S. (1985). Possible relationship of a 36megadalton Salmonella enteritidis plasmid to virulence in mice. Infection and Immunity 47, 831-833.

Pardon, P., Popoff, M. Y., Coynault, C., Marly, J. \& MiRAS, I. (1986). Virulence associated plasmids of Salmonella serotype typhimurium in experimental murine infection. Annales de l'Institut Pasteur/Microbiologie 137B, 47-60.

Popiel, I. \& Turnbull, P. C. B. (1985). Passage of Salmonella enteritidis and Salmonella thompson through chick ileal mucosa. Infection and Immunity 47, 786-792.

Popoff, M. Y., Miras, I., Coynault, C., Lasselin, C. \& Pardon, P. (1984). Molecular relationships between virulence plasmids of Salmonella serotypes typhimurium and dublin and large plasmids of other Salmonella serotypes. Annales de Microbiologie 135A, 389-398.

Smith, H. W. (1965a). The development of the flora of the alimentary tract in young animals. Journal of Pathology and Bacteriology 90, 495-513.

SMITH, H. W. $(1965 b)$. The immunization of mice, calves and pigs against Salmonella dublin and Salmonella cholerae-suis infection. Journal of Hygiene 63, 117-135.

Smith, H. W. (1972). The effect on virulence of transferring $\mathrm{R}$ factors to Salmonella typhimurium in vivo. Journal of Medical Microbiology 5, 451-457.

Smith, H. W. (1978). Is it safe to use Escherichia coli K12 in recombinant DNA experiments? Journal of Infectious Diseases 137, 655-660.

SMITH, H. W. \& Tucker, J. F. (1975). The effect of antibiotic therapy on the faecal excretion of Salmonella typhimurium by experimentally infected chickens. Journal of Hygiene 75, 275-292.

SMITH, H. W. \& TuCKeR, J. F. (1979). The effect on the virulence and infectivity of Salmonella typhimurium and Salmonella gallinarum of acquiring antibiotic resistance plasmids from organisms that had caused serious outbreaks of disease. Journal of Hygiene 83, 305-317.

SMITH, H. W. \& TUCKER, J. F. (1980). The virulence of Salmonella strains for chickens: their excretion by infected chickens. Journal of Hygiene 84, 479-488.

Suter, E. \& RAMSEIER, H. (1964). Cellular reactions in infection. Advances in Immunology 4, 117-173.

TAKEUCHI, A. (1967). Electron microscope studies of experimental Salmonella infection. I. Penetration into the intestinal epithelium by Salmonella typhimurium. American Journal of Pathology 50, 109-136.

TAKEUCHI, A. \& SPRINZ, H. (1967). Electron microscope studies of experimental Salmonella infection in the preconditioned guinea pig. II. Response of the intestinal mucosa to the invasion by Salmonella typhimurium. American Journal of Pathology 51, 137161. 
Terakado, N., Sekizaki, T., Hashimoto, K. \& NAITOH, S. (1983). Correlation between the presence of a fifty-megadalton plasmid in Salmonella dublin and virulence in mice. Infection and Immunity 41, 443-444.
Vandenbosch, J. L., Rabert, D. K. \& Jones, G. W. (1987). Plasmid-associated resistance of Salmonella typhimurium to complement activated by the classical pathway. Infection and Immunity 55, 2645-2652. 